\title{
The Organization of Novaculite Tool Production: Quarry-Workshop Debitage Comparisons
}

Mary Beth D. Trubitt

Arkansas Archaeological Survey, HSU Research Station

Follow this and additional works at: https://scholarworks.sfasu.edu/ita

Part of the American Material Culture Commons, Archaeological Anthropology Commons, Environmental Studies Commons, Other American Studies Commons, Other Arts and Humanities Commons, Other History of Art, Architecture, and Archaeology Commons, and the United States History Commons

Tell us how this article helped you.

This Article is brought to you for free and open access by the Center for Regional Heritage Research at SFA ScholarWorks. It has been accepted for inclusion in Index of Texas Archaeology: Open Access Gray Literature from the Lone Star State by an authorized editor of SFA ScholarWorks. For more information, please contact cdsscholarworks@sfasu.edu. 


\section{The Organization of Novaculite Tool Production: Quarry-Workshop Debitage Comparisons}

\section{Creative Commons License}

(c) (i) (8)

This work is licensed under a Creative Commons Attribution-NonCommercial 4.0 International License 


\title{
The Organization of Novaculite Tool Production: Quarry-Workshop Debitage Comparisons
}

\author{
Mary Beth Trubitt \\ Arkansas Archeological Survey
}

\begin{abstract}
Arkansas novaculite, outcropping in the Ouachita Mountains of Arkansas and Oklahoma, has been an important regional lithic resource for thousands of years. Because of the stone's durability, by-products of past novaculite procurement and tool production and use activities litter the landscape in southwest Arkansas. Recent work situates novaculite quarries in the broader context of tool production and exchange systems. This article focuses on the organization of tool production, and explores analytical techniques that can be used to identify spatial separation of the lithic reduction process between quarry, workshop, and habitation sites.
\end{abstract}

\section{INTRODUCTION}

Novaculite is a fine-grained siliceous material with few or no fossils that varies in color and texture; thin pieces are characteristically translucent (Holbrook and Stone 1979; Griswold 1892; Jeter and Jackson 1994). The Arkansas Novaculite formation outcrops along a 50-mile wide, 200-mile long band between Little Rock, Arkansas, and Broken Bow, Oklahoma, in the Ouachita Mountains (Figure 1). Sedimentary deposits were altered through diagenesis and metamorphosis during mountain building (Holbrook and Stone 1979; Keller et al. 1985; Steuart et al. 1984), and erosion has exposed folded and tilted beds of massive novaculite on mountain ridges.

Novaculite was the raw material of choice for stone-tool-using people living in the Ouachita Mountains at least as far back as the Archaic period. People living close to the sources could have procured novaculite directly from bedrock outcrops or in cobble form from river gravels (Waddell et al. 1995). It is a raw material that is ubiquitous on archeological sites in the Ouachita Mountains and is commonly found on sites in the adjacent Gulf Coastal Plain in southwest Arkansas and southeast Oklahoma (e.g., Schambach 1998). Some novaculite stone tools are found on sites as far away as Louisiana, Texas, and Mississippi. Those people living far from outcrop sources could have found novaculite locally as riverbed cobbles or in Pleistocene terrace gravels (e.g., Hemmings 1982; Perttula 1984). Novaculite for toolstone may also have been obtained by traveling directly to the outcrops or through trade (for example, novaculite artifacts are found on Poverty Point culture sites during the Late Archaic, ca. 3000-600 B.C., Jeter and Jackson 1994).

Quarrying novaculite for whetstones became an important industry during the nineteenth century around Hot Springs, Arkansas (Griswold 1892; Whittington 1969), and novaculite is still mined commercially today (Steuart et al. 1984). The nineteenth century exploitation of novaculite led to the first published descriptions of the aboriginal novaculite quarries in this area. In an 1844 publication, G. W. Featherstonhaugh (1968:110-111) described circular pit features at a novaculite quarry near Hot Springs, and connected raw material procurement at quarry sites with debris from tool manufacture seen at habitation sites elsewhere in the area. William H. Holmes (1891) visited a novaculite quarry site near Hot Springs in 1890, and used it (along with another 


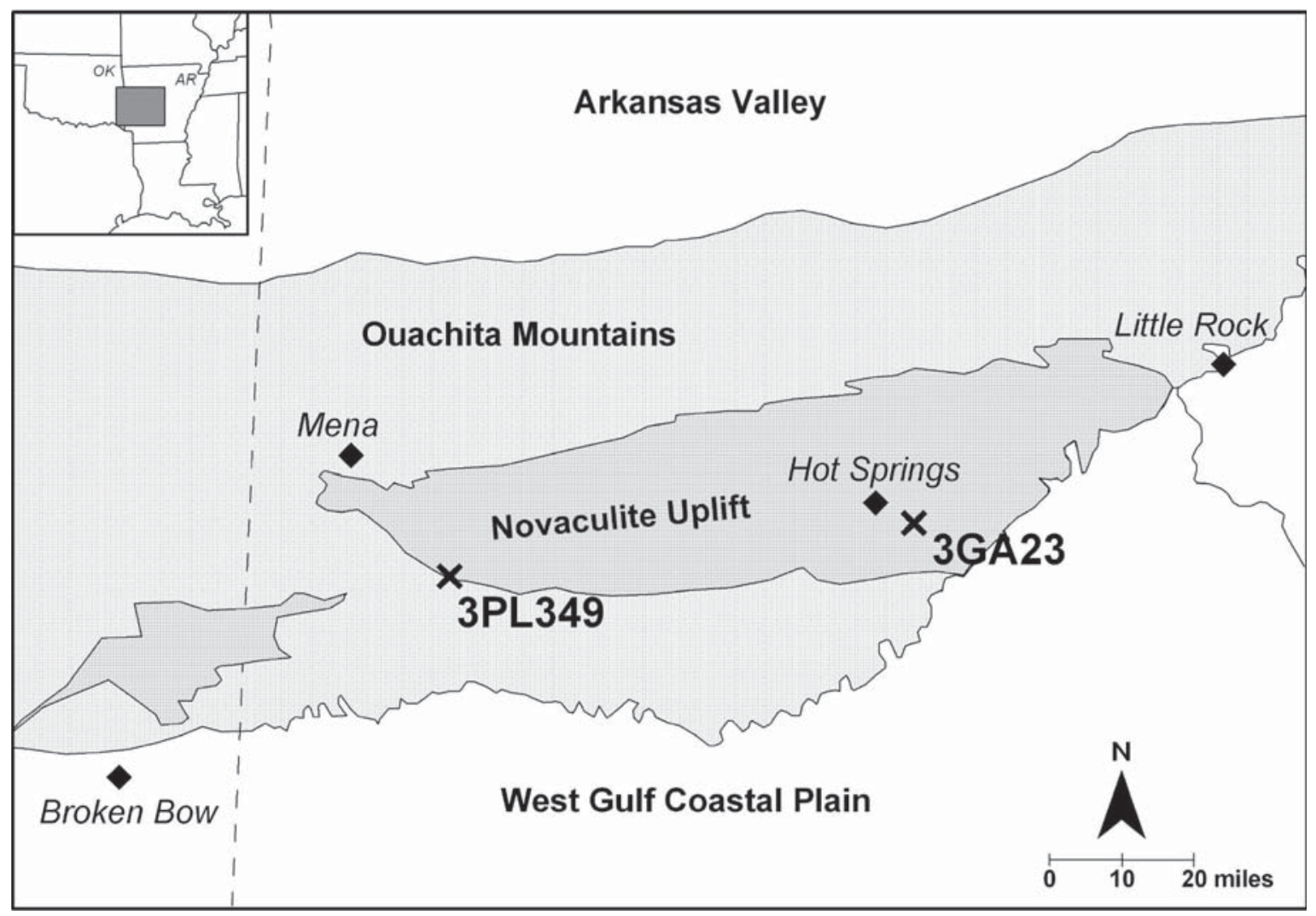

Figure 1. Location of sites 3PL349 and 3GA23 against physiographic provinces.

site visited by W. P. Jenney) as examples in his treatise on aboriginal North American stone quarries (Holmes 1974:196-200). In addition, Holmes (1891:Plate III) illustrated a series of rough bifaces, bifacial preforms, and finished dart points, and suggested that preliminary roughing out of blanks was done at quarries on the mountain ridges while final tool finishing took place at sites in adjacent valleys.

In the decades since the 1970s, research by professional archeologists has added numerous novaculite quarries to the Arkansas site files and produced descriptions of surface features at quarries (e.g., Baker 1974; Etchieson 1997). Research has also expanded on Holmes's basic model of toolstone procurement and tool manufacture. Projects at sites - many in the Ouachita National Forest—show us, for example, that streambed cobbles were a minor source of raw material as compared to bedrock outcrops (Thomas et al. 1982:275; Waddell 1995:106-120; see also Coleman 2002:52-53, 56-57); that lithic reduction and tool manufacturing was a major activity at some sites (e.g., Coleman et al. 1999; Early 2000; Martin 1982:Table 6; Stewart 1995; Thomas et al. 1982:273-276); and that thick bifaces were produced at some workshop sites to be used elsewhere (e.g., Coleman 2003).

I, along with Tom Green and Ann Early, published a research design for investigating novaculite quarry sites that details past work and outlines plans for future work. In it, we situate the quarries in the broader context of novaculite tool production and exchange systems (Trubitt et al. 2004). Increasingly, archeologists are interested not just in manufacturing techniques and technologies, but in understanding the social, economic, and political aspects of tool production, distribution, and use. In the lithics literature, these concerns have been discussed as 
"organization of technology," as the chaine opératoire or reconstructing operational sequences, or as the "anthropology of technology." Since I am interested more broadly in craft production and exchange, I approach lithics through the "organization of production" literature. Here, I find Cathy Costin's (2001) discussion of the components of craft "production systems"- the meanings and uses of the crafted objects, the procurement of raw materials and production techniques, the spatial and social organization of production, the organization and mechanisms for distribution, and the crafters or artisans as well as the "consumers" of the objects- to be a helpful framework. While research may concentrate on one or another of these components, viewing tool production, exchange, and consumption as a system gives us the 'big picture' that allows us to relate artifacts, features, and sites across a region with each other and with the people who made and used novaculite tools in the past.

I am concentrating in this article on the organization of novaculite tool production. We have several research possibilities. Were quarrying and tool production spatially separated or were a variety of activities done at quarries and workshops as well as habitation sites? How was production organized in terms of control of production and access to lithic resources? Was quarrying and making stone tools something that every household in the area did for itself or did only certain groups visit quarries? How did toolstone procurement fit into the seasonal round and task schedules? Here I address one question: was preliminary reduction done at quarries and bifacial thinning and tool production done at workshop sites away from the outcrops? To answer this, we can look at tools and at their production debris. Differences in debitage patterning between sites help to characterize the spatial organization of production, an important first step towards understanding the social organization of tool production.

We expect that lithic debris and tools discarded at different kinds of sites should reflect spatial separation of the tool manufacturing and use sequence. For novaculite, we have a working model that places the initial testing of toolstone and perhaps knapping of large bifacial blanks at quarry locations, and further bifacial reduction and finishing of bifacial tools like dart and arrow points at more distant workshop or habitation sites. Reduction at or near quarries is expected to produce larger debitage, more shatter, hard hammer percussion flakes, debitage with cortex, few biface thinning flakes, few indications of heat treatment, and bifaces discarded in earlier stages of reduction (e.g., Ahler and VanNest 1984; Birmingham 1984; Dowd 1998; Hatch 1994; Hatch and Miller 1985; Johnson 1981, 1984, 1989; Stoltman et al. 1984).

Several archeological projects from the southern Ouachita Mountains have used debitage analysis to infer novaculite tool reduction sequences and strategies. Using site survey data from the Ouachita National Forest, David Waddell (1995; Waddell and Waddell 1992; Waddell et al. 1995) employed principal components analysis and cluster analysis to group sites into lithic procurement and manufacturing "activity sets." The activity sets were based on types of tools, cores, and bifaces, and on the debitage analysis (using ratios of decortication to interior flakes and bifacial thinning to interior flakes). Roger Coleman $(2002,2003)$ used typological analyses of novaculite debitage to identify technological strategies (for example, reduction of unidirectional or bifacial cores, use of freehand or bipolar percussion) and reduction stages present at two Ouachita National Forest sites. Mass analysis of novaculite debitage was employed during the analyses of sites tested during the Shady Lake project in Polk County and the Winding Stair project in Montgomery County. At the Middle Archaic Hill site (3PL343), debitage size-sorting showed that the majority of novaculite debris, by weight, was $2.54 \mathrm{~cm}$ or larger, suggesting an earlier stage of reduction was done there (Coleman et al. 1999; Stewart 1995). At the Winding Stair sites (3MN383, 3MN979, and 3MN496), the majority of novaculite debris, by count, was small $(1.27 \mathrm{~cm}$ or less), suggesting debris mainly from finishing, using, and reworking tools (Coleman and Guendling 2000:53; Guendling 2000:65). 
In this article, I develop an analysis protocol that can be used to compare novaculite debris from different sites to interpret their roles in the larger production and exchange system(s). I am interested primarily in changes in lithic reduction strategies across space, what reduction stages (or parts of the reduction continuum) were done closer and further from quarries, and whether bifacial reduction was predominant. While bifaces and finished tools will be important in the analysis and comparison of these sites, the novaculite debitage is my current focus. I need an analysis protocol that can be used with the large debris samples that result from quarry or workshop excavations. Here, I use both individual flake attribute analysis and mass analysis techniques, as combining analytical techniques has been found to produce more valid interpretations than reliance on one technique alone (see discussions and examples in Andrefsky 2001; Bradbury 1998; Carr and Bradbury 2001; Koldehoff and Carr 2001; Odell 2004:118-132; Root 2004; Shott 1994). Recently, Bradbury and Carr (2004) offered a "pragmatic" approach to debitage analysis that combines mass analysis and individual flake analysis techniques. They found that two individual flake attributes (identifying blocky debris or shatter, and counting flake platform facets) as well as counts/weights from debitage mass analysis, could accurately differentiate between core reduction and tool production in experimental and simulated assemblages, and showed good potential for the analysis of archeological assemblages. I use a similar approach to debitage analysis in this project.

\section{THE PROJECT}

Two excavated assemblages form the data sets for comparison and discussion. The first is from a novaculite quarry site (3PL349) in the southern Ouachita Mountains (see Figure 1) that was mapped and tested during the annual training program held by the Arkansas Archeological Society and Arkansas Archeological Survey (AAS) in 1993. Quarry features included battered, exposed bedrock, a trench, and large piles of waste flakes and hammerstones. Two 1 x $1 \mathrm{~m}$ test units were excavated, and thousands of pieces of debitage were recovered before battered bedrock was hit at $20 \mathrm{~cm}$ below surface. While a report on the project has been published (Coleman et al. 1999; Hilliard 1995), a complete artifact analysis was not done at the time. I have begun work on analyzing the assemblage, assisted by Henderson State University (HSU) students and Arkansas Archeological Society volunteers.

In the summer of 2004, I directed the Henderson State University Archeological Field School excavations at a multi-component site near Hot Springs, Arkansas (3GA23). The site is part of a larger site complex first investigated in 1917 by M. R. Harrington, who described residential mounds and associated village debris that he dated to the Caddo period as well as a deep midden deposit in one area that he interpreted as an earlier preceramic (Archaic period) lithic workshop (Harrington 1920:103-117). The site has suffered from years of collecting and looting, as well as flooding from the damming of the Ouachita River and recent residential development, but our testing showed that there are some intact deposits remaining. Stratigraphically, we found evidence of a dense black midden that dates to the Fourche Maline culture of the Woodland period (ca. 650 B.C.-A.D. 950), overlying deposits containing Archaic period diagnostics. Novaculite debitage is very heavy across the site, which appears to be a workshop and habitation located downstream from a major novaculite quarry (3GA22 [Trubitt 2005]). Jeffrey Gaskin (then lab assistant at the AAS/HSU Research Station) was responsible for much of the initial lab processing and cataloguing.

We started with mass analysis of debitage, using size-sorting to identify the reduction in debitage size as novaculite was worked and carried further from its source. Mass analysis has advantages in allowing rapid characterization of large samples of flakes, such as are obtained from quarry or workshop contexts. Stanley Ahler (1989a, 1989b) lays out the rationale and experimental data behind mass analysis of debitage, arguing 
that different stages in the manufacture or reduction sequence and different flaking techniques result in different size-grade distribution patterns (see also Andrefsky 2001:3-6, 2004; Odell 2004:130-132; Shott 1994:86-100 for discussions of mass analysis). He emphasizes the importance of experimentation in interpreting results (something I have not undertaken for novaculite at this point), and cautions that archeological samples often have mixtures of several technologies and reduction stages, complicating interpretation. Using experimental replication data, Toby Morrow (1997:56-57) found that mass analysis is a good method for distinguishing the debitage produced during the stages of biface reduction and point manufacture, and that proportion of flakes in each size grade by weight (more so than counts) showed the pattern of decreasing flake size with reduction. However, he found that mass analysis was not a robust method for differentiating technological strategies, such as identifying core reduction as opposed to biface reduction.

Following Ahler (1989b), we size-sorted novaculite debitage from 3PL349 and 3GA23 through a series of geological standard test sieves (a 1" with $25 \mathrm{~mm}$ or 0.9843 " openings, a 1/2" with $12.5 \mathrm{~mm}$ or 0.50 " openings, a $1 / 4$ " with $6.3 \mathrm{~mm}$ or 0.25 " openings, and a No. 7 with $2.8 \mathrm{~mm}$ or 0.11 " openings), counting and weighing (in grams) each size fraction. The excavated samples from 3PL349 and 3GA23 were screened through 1/4" mesh in the field, but I have begun to collect standard flotation samples from excavated levels to recover the full range of debitage and allow better comparison between deposits and between sites. This article reports results from a sample of artifacts from one level from one of the 3PL349 test units (1/4" mesh dry-screening) and the flotation samples collected and processed from 3GA23 (heavy fractions caught on 1/16" window screen). While raw material type and presence of heat treatment are of interest in the research, this article deals just with novaculite as a unified raw material category.

The size-sorting distributions (Table 1) clearly show that the quarry site 3PL349 has more larger/heavier debitage than does the postulated workshop/habitation site 3GA23. The cumulative frequency charts (Figure 2a-b) use the three larger size grades. The straight frequency chart (Figure 3) uses all four size grades, and graphically shows that the bulk of the debitage by weight is greater than 1" in size for the 3PL349 sample, whereas the $1 / 4$ " sieve caught most of the debitage by weight from 3GA23. Assuming decreasing size with later stages of reduction (or the absence of large-sized debris from later reduction), these patterns suggest that earlier reduction took place at 3PL349, the quarry site, while most of the debitage from 3GA23 is from later in the reduction process. The size-sorting distributions can also be compared with other reported site assemblages (e.g., Trubitt et al. 2004:Figure 5).

The presence or absence of cortex is the one attribute that Ahler (1989b:90) records as part of mass analysis (and he notes the presence or absence of cortex rather than quantifying percentage of dorsal cortex or categorizing flakes as primary, secondary, or tertiary decortication flakes). For massive or bedrock outcrop sources of toolstone such as Arkansas Novaculite, cortex typically takes the form of weathered surfaces on blocky pieces (or cobbles from stream gravels). (Differentiating humanly-produced angular or blocky debris or shatter from the natural talus that has weathered and broken from outcrops is often a problem at quarry sites [Andrews et al. 2004:68-71; Funk 2004:54]. For this analysis, any piece that was weathered on all surfaces was discarded as natural.) For these two site samples, I recorded presence/absence of cortex for debris caught in the $1 ", 1 / 2 "$, and $1 / 4$ " sieves. Higher proportions of debitage ( $31 \%$ by count, $41 \%$ by weight, total $n=1218,17,355 \mathrm{~g}$ ) from 3PL349 have some cortex or weathered surfaces as compared with the 3 GA23 debitage sample ( $5 \%$ by count, $19 \%$ by weight, total $n=3492,3632 \mathrm{~g}$ ). Most of the novaculite was brought to $3 \mathrm{GA} 23$ with the cortex already removed.

There is a growing literature on the interpretation of mass analysis data using experimental data sets and plotting size and cortex variables using several measures, using logarithmic or Weibull transformations of data, or 


\begin{tabular}{|c|c|c|c|c|c|c|c|c|c|c|}
\hline \multicolumn{11}{|c|}{ Size sorting using 1", 1\%, 1/4 size grades. } \\
\hline & \multicolumn{2}{|c|}{ 1" } & \multicolumn{2}{|c|}{$1 / 2^{\prime \prime}$} & \multicolumn{2}{|c|}{$1 / 4^{\prime \prime}$} & \multicolumn{2}{|c|}{ Total: } & & \\
\hline & count & weight & count & weight & count & weight & count & weight & & \\
\hline 3PL349 & 288 & 12112.8 & 631 & 4845.4 & 299 & 397.0 & 1218 & 17355.2 & & \\
\hline $3 G A 23$ & 21 & 614.1 & 400 & 1380.0 & 3071 & 1637.4 & 3492 & 3631.5 & & \\
\hline \multicolumn{11}{|c|}{ Cumulative frequency distributions. } \\
\hline & \multicolumn{3}{|c|}{ count: } & & & \multicolumn{3}{|c|}{ weight $(g)$ : } & & \\
\hline & 1" & $1 / 2^{\prime \prime}$ & $1 / 4^{\prime \prime}$ & & & $1^{\prime \prime}$ & $1 / 2^{\prime \prime}$ & $1 / 4^{\prime \prime}$ & & \\
\hline 3PL349 & $23.6 \%$ & $75.5 \%$ & $100.0 \%$ & & & $69.8 \%$ & $97.7 \%$ & $100.0 \%$ & & \\
\hline $3 G A 23$ & $0.6 \%$ & $12.1 \%$ & $100.0 \%$ & & & $16.9 \%$ & $54.9 \%$ & $100.0 \%$ & & \\
\hline \multicolumn{11}{|c|}{ Size sorting using 1", 1\%, 11/4, 1/8" size grades. } \\
\hline & \multicolumn{2}{|c|}{$1 "$} & \multicolumn{2}{|c|}{$1 / 2^{\prime \prime}$} & \multicolumn{2}{|c|}{$1 / 4^{\prime \prime}$} & \multicolumn{2}{|c|}{$1 / 8^{\prime \prime}$} & \multicolumn{2}{|c|}{ Total: } \\
\hline & count & weight & count & weight & count & weight & count & weight & count & weight \\
\hline $3 P L 349$ & 288 & 12112.8 & 631 & 4845.4 & 299 & 397.0 & 26 & 46.2 & 1244 & 17401.4 \\
\hline $3 G A 23$ & 21 & 614.1 & 400 & 1380.0 & 3071 & 1637.4 & 13085 & 845.5 & 16577 & 4477.0 \\
\hline \multicolumn{11}{|c|}{ Frequency distributions. } \\
\hline & \multicolumn{5}{|c|}{ count: } & \multicolumn{5}{|c|}{ weight $(g)$ : } \\
\hline & 1" & $1 / 2^{\prime \prime}$ & $1 / 4^{\prime \prime}$ & $1 / 8^{\prime \prime}$ & & 1" & $1 / 2^{\prime \prime}$ & $1 / 4^{\prime \prime}$ & $1 / 8^{\prime \prime}$ & \\
\hline $3 P L 349$ & $23.2 \%$ & $50.7 \%$ & $24.0 \%$ & $2.1 \%$ & $100.0 \%$ & $69.6 \%$ & $27.8 \%$ & $2.3 \%$ & $0.3 \%$ & $100.0 \%$ \\
\hline $3 G A 23$ & $0.1 \%$ & $2.4 \%$ & $18.5 \%$ & $78.9 \%$ & $100.0 \%$ & $13.7 \%$ & $30.8 \%$ & $36.6 \%$ & $18.9 \%$ & $100.0 \%$ \\
\hline
\end{tabular}

employing discriminant analysis (Ahler 1989a, 1989b; Ingbar et al. 1992; Bradbury 1998:273-275; Patterson 1990; Stahle and Dunn 1982, 1984). Computing and plotting data from 3PL349 and 3GA23 highlights the differences between these samples (Table 2 and Figure 4) in terms of earlier versus later in the reduction process, but 'reading' reduction stage or technological strategy from placement on a chart generated from other areas might be pushing the data at this point.

At the same time as cortex was recorded on size-sorted debitage from the 1", 1/2", and 1/4" sieves, I pulled flakes (distinguished by an intact bulb of percussion and striking platform) for further examination, and quantified shatter (angular chipping debris). More shatter is expected at or near quarries as by-products of earlier stages of reduction, heavy percussion flaking, and core reduction (Bradbury and Carr 2004:69; Hatch 1994:36, 40-41; Johnson 1981:101-114; T. Morrow 1997:62). A higher proportion of the debitage from 3PL349 was identified as shatter ( $84 \%$ by count, $90 \%$ by weight) than in the sample from 3GA23 (11\% by count, $28 \%$ by weight). If shatter is a typical residue of percussion flaking and earlier stages of reduction, then these activities were more common at 3PL349 than at 3GA23. Very high proportions of shatter have been identified for quarry sites elsewhere (e.g., Hatch 1994:36, 40-41).

Attribute analysis of individual flakes is more time-consuming, but can reveal important patterning. Frequently, analysts use a typological analysis and identify bifacial thinning flakes as evidence for biface production or bifacial tool finishing, but definitions of this category vary somewhat from researcher to researcher (Andrews et al. 2004; Parry and Kelly 1987). Here, I focus on several attributes of flake striking platforms. The morphology 


\section{Figure 2. Mass Analysis of Debitage Cumulative Frequency, Count}

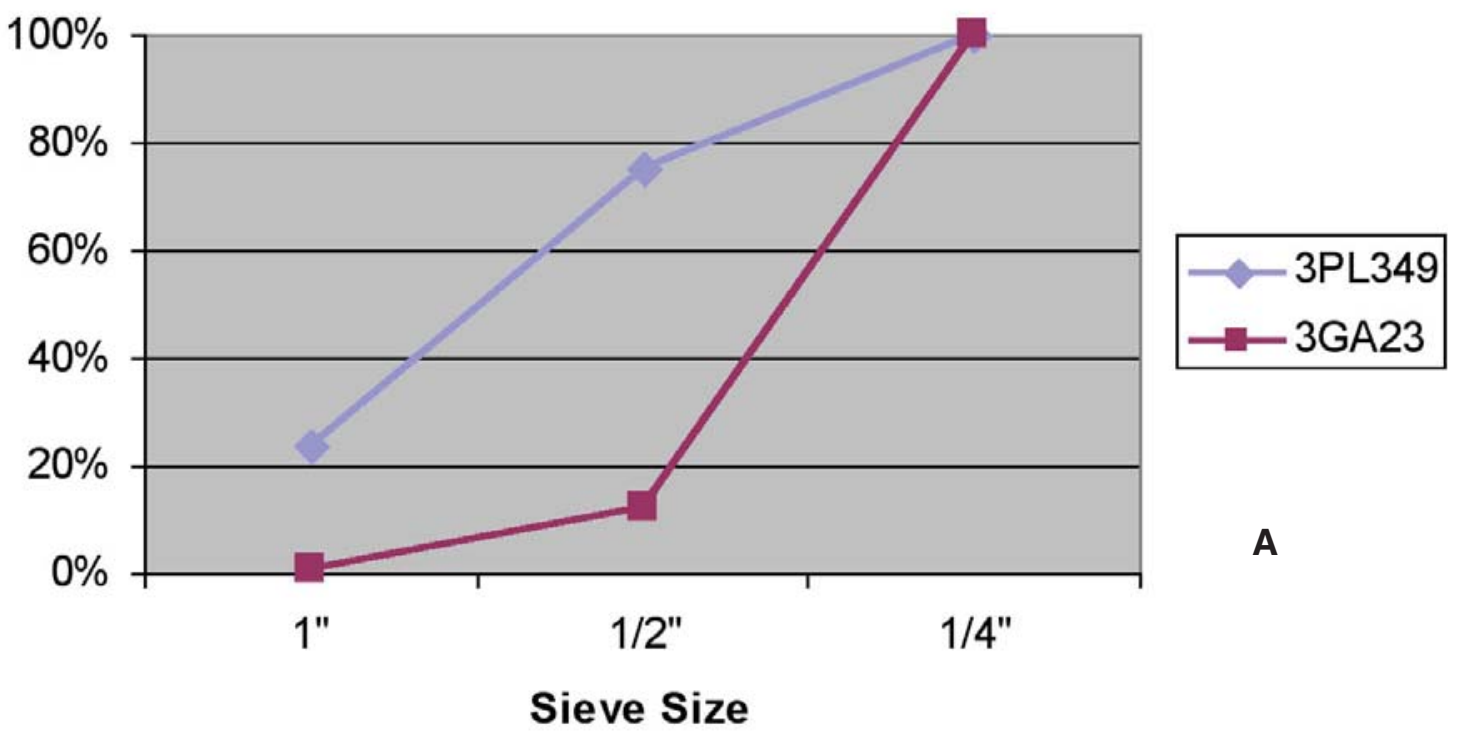

\section{Cumulative Frequency, Weight (g)}

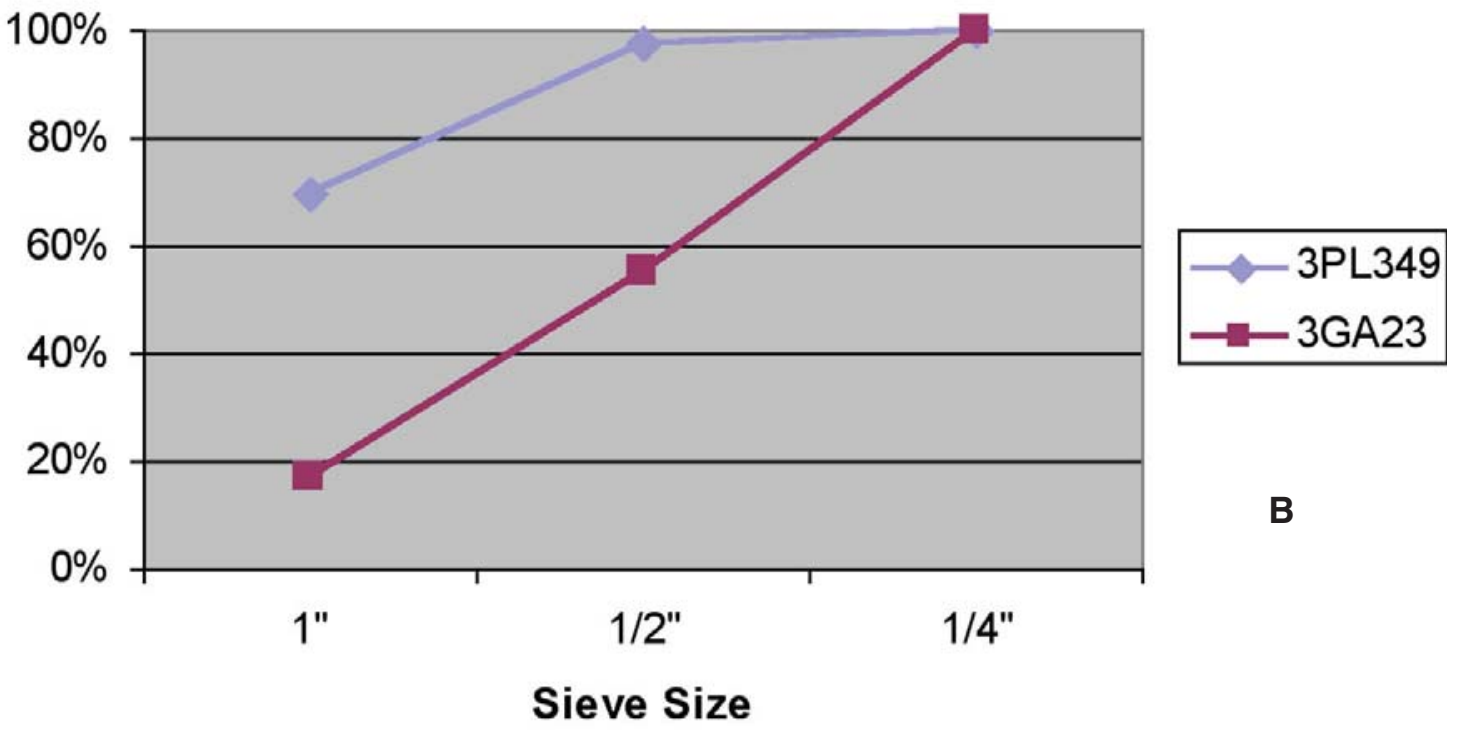

Figure 2. Mass Analysis of Debitage Cumulative Frequency: a, Count; b, weight. 


\section{Figure 3. Mass Analysis of Debitage Weight Frequency by Sieve Size}

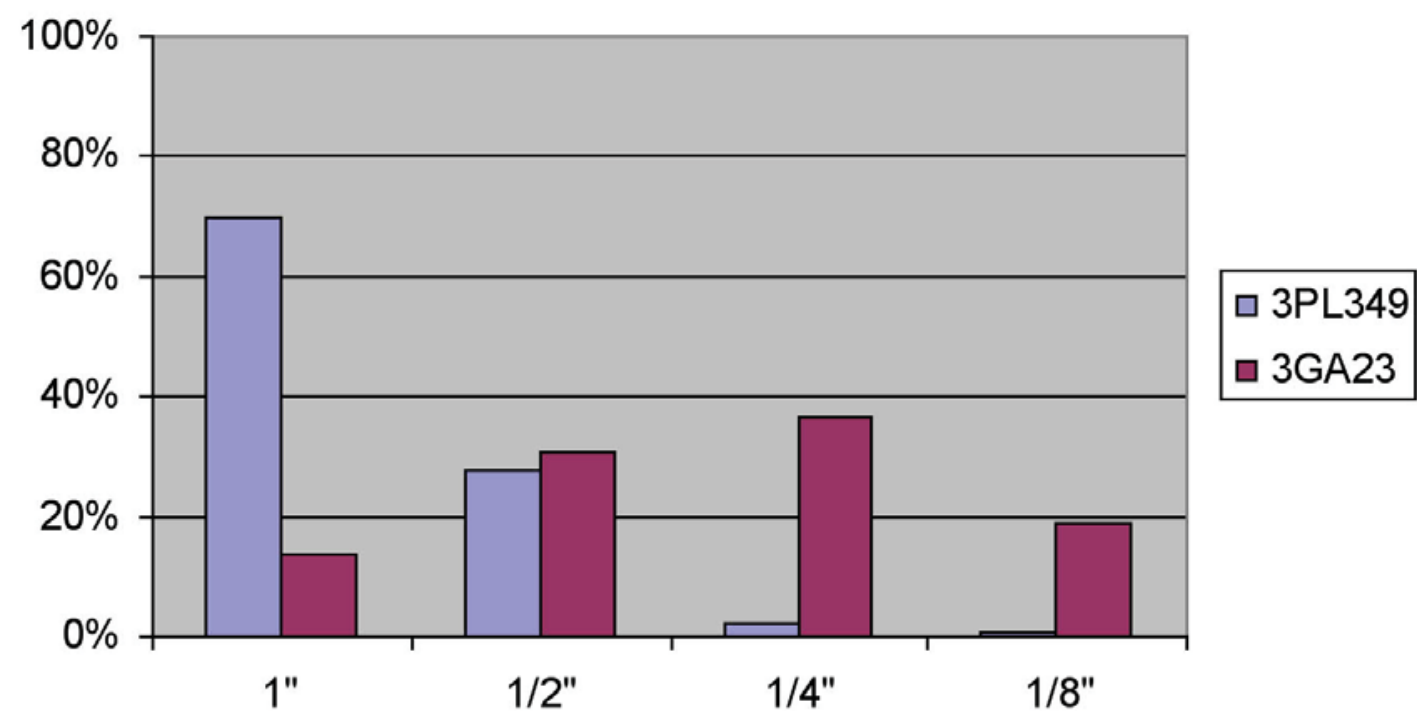

Figure 3. Mass Analysis of Debitage Weight Frequency by Sieve Size.

or configuration of striking platforms has been used to differentiate biface from core production (or bifacial cores from other types of cores), differentiate between hard and soft hammer or pressure flaking, and identify reduction stage (Andrefsky 2001:9; Magne 1985; J. Morrow 1997; T. Morrow 1997:62-63).

Using experimental data, Martin Magne (1985:111-125) found that a set of attributes recorded from individual flakes (weight, dorsal scar count and 'complexity,' platform scar count, dorsal angle of platform, and cortex amount) could be used to correctly predict reduction stage as early, middle, and late (higher accuracy levels were found in predicting debris from early stage reduction and bifacial and bipolar reduction; the byproducts of middle and late stage reduction were often mis-classified). Platform scar count was identified as the most important attribute in differentiating between reduction stages, and a key attribute for identifying bifacial reduction. When he turned to the archeological assemblages, platforms with cortex or one flake scar were linked with early stage reduction, those with two scars with middle stage, and platforms with three or more scars with late stage and with bifacial reduction (Magne 1985:128-129, 160). While different methods of describing/quantifying striking platform flake scars have been used, this attribute seems to be a strong predictor or indicator of reduction stage and of bifacial reduction (Andrews et al. 2004:72-75; Bradbury and Carr 2004; Carr and Bradbury 2001; Johnson 1981:133-134; Magne 1985:111-129, 160-161; J. Morrow 1996:146-147 and Figure 26, 1997; T. Morrow 1997; Odell 2004:126-128; Parry and Kelly 1987:291-292; but see Shott [1996] on the reduction sequence as a continuum rather than stages). Striking platform morphology is included by Shott (1994:77-81) in his suggested "minimum attribute set" for comparative studies that use debitage analysis. Striking platform preparation (indicated by abrasion) has also been linked with bifacial reduction, and with soft hammer percussion, indirect percussion, and pressure flaking techniques (Andrews et al. 2004:74; T. Morrow 1997:62; Parry and Kelly 1987:291-292). Lipping is another attribute associated with soft hammer percussion, wooden billets, and/or pressure flaking (Crabtree 1972:44, 74-75; Dowd 1998:134; Johnson 1981:131-132). 


\begin{tabular}{|c|c|c|c|c|c|c|c|c|c|c|c|c|}
\hline \multicolumn{13}{|c|}{ Comparisons by Size Grades: } \\
\hline & \multicolumn{2}{|l|}{$1^{\prime \prime}$} & \multicolumn{2}{|c|}{$1 / 2 "$} & \multicolumn{2}{|c|}{$1 / 4 "$} & \multicolumn{2}{|c|}{ Total: } & \multicolumn{2}{|c|}{$1 / 8^{\prime \prime}$} & \multicolumn{2}{|c|}{ Total: } \\
\hline & $c t$ & $w t$ & $c t$ & $w t$ & $c t$ & $w t$ & $c t$ & $w t$ & $c t$ & $w t$ & $c t$ & $w t$ \\
\hline \multicolumn{13}{|l|}{$3 P L 349$} \\
\hline Total: & \begin{tabular}{l|l}
288 & 1
\end{tabular} & 12112.8 & 631 & 4845.4 & 299 & 397.0 & 1218 & 17355.2 & 26 & 46.2 & 1244 & 17401.4 \\
\hline \multirow{2}{*}{ Cortex: } & 114 & 5293.8 & 200 & 1721.0 & 58 & 93.7 & 372 & 7108.5 & & & & \\
\hline & $39.6 \%$ & $43.7 \%$ & $31.7 \%$ & $35.5 \%$ & $19.4 \%$ & $23.6 \%$ & $30.5 \%$ & $41.0 \%$ & & & & \\
\hline \multirow{2}{*}{ Shatter: } & \begin{tabular}{l|l}
251 & 1 \\
\end{tabular} & 10990.1 & 530 & 4308.3 & 238 & 356.1 & 1019 & 15654.5 & & & & \\
\hline & $87.2 \%$ & $90.7 \%$ & $84.0 \%$ & $88.9 \%$ & $79.6 \%$ & $89.7 \%$ & $83.7 \%$ & $90.2 \%$ & & & & \\
\hline \multirow{2}{*}{$\begin{array}{l}\text { PRB } \\
\text { Flakes: }\end{array}$} & 28 & 994.7 & 51 & 370.8 & 17 & 13.2 & 96 & 1378.7 & & & & \\
\hline & $9.7 \%$ & $8.2 \%$ & $8.1 \%$ & $7.7 \%$ & $5.7 \%$ & $3.3 \%$ & $7.9 \%$ & $7.9 \%$ & & & & \\
\hline \multicolumn{13}{|l|}{$3 G A 23$} \\
\hline Total: & 21 & 614.1 & 400 & 1380.0 & 3071 & 1637.4 & 3492 & 3631.5 & 13085 & 845.5 & 16577 & 4477.0 \\
\hline \multirow{2}{*}{ Cortex: } & 9 & 407.2 & 45 & 177.6 & 114 & 97.3 & 168 & 682.1 & & & & \\
\hline & $42.9 \%$ & $66.3 \%$ & $11.3 \%$ & $12.9 \%$ & $3.7 \%$ & $5.9 \%$ & $4.8 \%$ & $18.8 \%$ & & & & \\
\hline \multirow{2}{*}{ Shatter: } & 9 & 426.2 & 59 & 337.0 & 305 & 261.9 & 373 & 1025.1 & & & & \\
\hline & $42.9 \%$ & $69.4 \%$ & $14.8 \%$ & $24.4 \%$ & $9.9 \%$ & $16.0 \%$ & $10.7 \%$ & $28.2 \%$ & & & & \\
\hline \multirow{2}{*}{$\begin{array}{l}\text { PRB } \\
\text { Flakes: }\end{array}$} & 7 & 122.5 & 188 & 635.0 & 877 & 523.7 & 1072 & 1281.2 & & & & \\
\hline & $33.3 \%$ & $19.9 \%$ & $47.0 \%$ & $46.0 \%$ & $28.6 \%$ & $32.0 \%$ & $30.7 \%$ & $35.3 \%$ & & & & \\
\hline \multicolumn{13}{|c|}{ Percentage Cortex by Count, 1", 1/2", 1/4" Size Grades: } \\
\hline & $1 "$ & $1 / 2 "$ & $1 / 4 "$ & Total & & & & & & \\
\hline $3 P L 349$ & $39.6 \%$ & $31.7 \%$ & $19.4 \%$ & $30.5 \%$ & \multicolumn{3}{|c|}{ (sample, $\mathrm{n}=1218$ ) } & & & & & \\
\hline $3 G A 23$ & $42.9 \%$ & $11.3 \%$ & $3.7 \%$ & $4.8 \%$ & (sample, & $n=3492)$ & & & & & & \\
\hline Mean De & ge Weights & ts, 1", 1/2", 1 & 1/4" Size G & Grades $(g)$ & & & & & & & & \\
\hline & 1" & $1 / 2^{\prime \prime}$ & $1 / 4 "$ & Total & & & & & & & & \\
\hline $3 P L 349$ & 42.1 & 7.7 & 1.3 & 14.2 & (sample, & $\mathrm{n}=1218$ ) & & & & & & \\
\hline $3 G A 23$ & 29.2 & 3.5 & 0.5 & 1.0 & (sample, & $\mathrm{n}=3492)$ & & & & & & \\
\hline Count $R_{a}$ & s, 1", 1/2", 1 & $1 / 4 "$ to $1 / 8^{\prime \prime}$ : & & & & & & & & & & \\
\hline & 1" & $1 / 2 "$ & $1 / 4 "$ & & $1 / 8^{\prime \prime}$ & & & & & & & \\
\hline & count & count & count & Total: & count & Ratio & & & & & & \\
\hline $3 P L 349$ & 288 & 631 & 299 & 1218 & 26 & 0.02 & & & & & & \\
\hline $3 G A 23$ & 21 & 400 & 3071 & 3492 & 13085 & 3.75 & & & & & & \\
\hline Count $/ W$ & ht Comparis & isons, $1 / 2$ " S & Size Grade & & & & & & & & & \\
\hline & $1 / 2^{\prime \prime c}$ & count & $1 / 2^{\prime \prime}$ we & eight (g) & & & & & & & & \\
\hline $3 P L 349$ & 631 & $51.8 \%$ & \begin{tabular}{l|l}
0 & 4845.4
\end{tabular} & $27.9 \%$ & (sample, & $n=1218$ & $17355.2 \mathrm{~g}$ & & & & & \\
\hline $3 G A 23$ & 400 & $11.5 \%$ & \begin{tabular}{l|l}
0 & 1380.0
\end{tabular} & $38.0 \%$ & (sample, & $\mathrm{n}=3492,3$ & $3631.5 \mathrm{~g})$ & & & & & \\
\hline
\end{tabular}



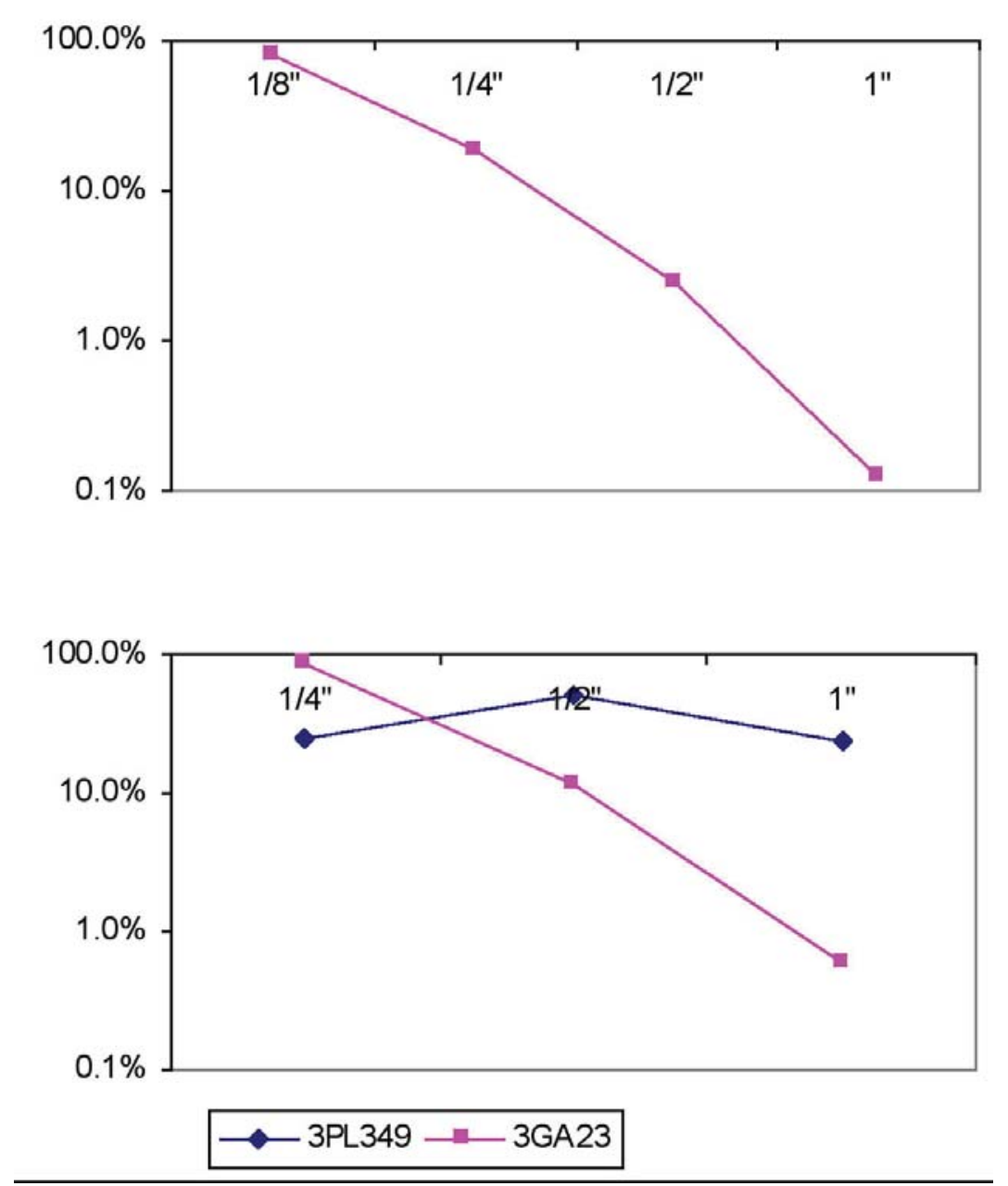

Figure 4. Log-linear Plots of Size-sorting Data.

I examined individual novaculite flakes (with identifiable platforms) caught in the 1 " and $1 / 2$ " sieves from the 3PL349 and 3GA23 samples under magnification to record striking platform morphology (counting flake scars or facets as $0 /$ cortical, 1,2 , and 3 or more), as well as to measure striking platform width and thickness (parallel and perpendicular to the ventral/bulbar surface of the flake) by calipers in millimeters, and to note the presence/absence of lipping on ventral edges of striking platforms and microchipping or abrasion on dorsal edges of striking platforms.

In the sample of flakes greater than $1 / 2$ " with identifiable platforms, a bare majority of flakes from 3PL349 (38 of 73 or $52 \%$ ) had cortical ( 0 scar) or simple/flat (1 scar) platforms. From 3GA23, a majority of flakes (117 of 170 or $69 \%$ ) had multi-scar (2 or 3/3+ scars) platforms (Figure 5). A relatively large proportion of the 3PL349 sample had 2 or 3 scars recorded on striking platforms, but few of these show platform abrasion/chipping or lipping, compared with the sample from 3GA23 (Table 3). Most of the flakes from 3GA23 have small striking platforms (63\% of the sample had measured striking platforms between 1-3 mm thick, Table 4 and Figure 6). Since all flakes examined were from the $>1 "$ and $>1 / 2$ " size grades, this is not necessarily a reflection of the smaller size of the flakes from 3GA23. The smaller platforms are an indication of a later stage in the bifacial 
reduction sequence (T. Morrow 1997:65; see also Coleman [2002:53 and Figure 13] on striking platform width). Graphically, plots of striking platform metrics comparisons show the concentration of small multiscar platforms on the flakes from 3GA23 (Figure 7). The individual flake analysis results suggest that earlier reduction (and hard hammer percussion) took place at 3PL349 whereas later reduction, bifacial reduction, and platform preparation (and soft hammer percussion) was done at 3GA23. The results of the mass analysis and the individual flake analysis are complementary.

\begin{tabular}{|c|c|c|c|c|c|c|}
\hline \multicolumn{7}{|c|}{ Platform Facet Count: } \\
\hline & 0 & 1 & 2 & $3 / 3+$ & Total & Indet. \\
\hline \multirow[t]{2}{*}{$3 P L 349$} & 8 & 30 & 18 & 17 & 73 & 6 \\
\hline & $11.0 \%$ & $41.1 \%$ & $24.7 \%$ & $23.3 \%$ & $100.0 \%$ & \\
\hline \multirow[t]{2}{*}{$3 G A 23$} & 9 & 44 & 50 & 67 & 170 & 25 \\
\hline & $5.3 \%$ & $25.9 \%$ & $29.4 \%$ & $39.4 \%$ & $100.0 \%$ & \\
\hline \multicolumn{7}{|c|}{ Striking Platform Configuration: } \\
\hline \multicolumn{7}{|c|}{ Flakes with 2 or $3 / 3+$ flake scars on striking platform, and... } \\
\hline & & & \multicolumn{3}{|c|}{ Chipping/Abrasion } & Lipping \\
\hline 3PL349 & $\mathrm{n}=35$ & & & $11 \%$ & & $0 \%$ \\
\hline $3 G A 23$ & $n=117$ & & & $55 \%$ & & $26 \%$ \\
\hline
\end{tabular}

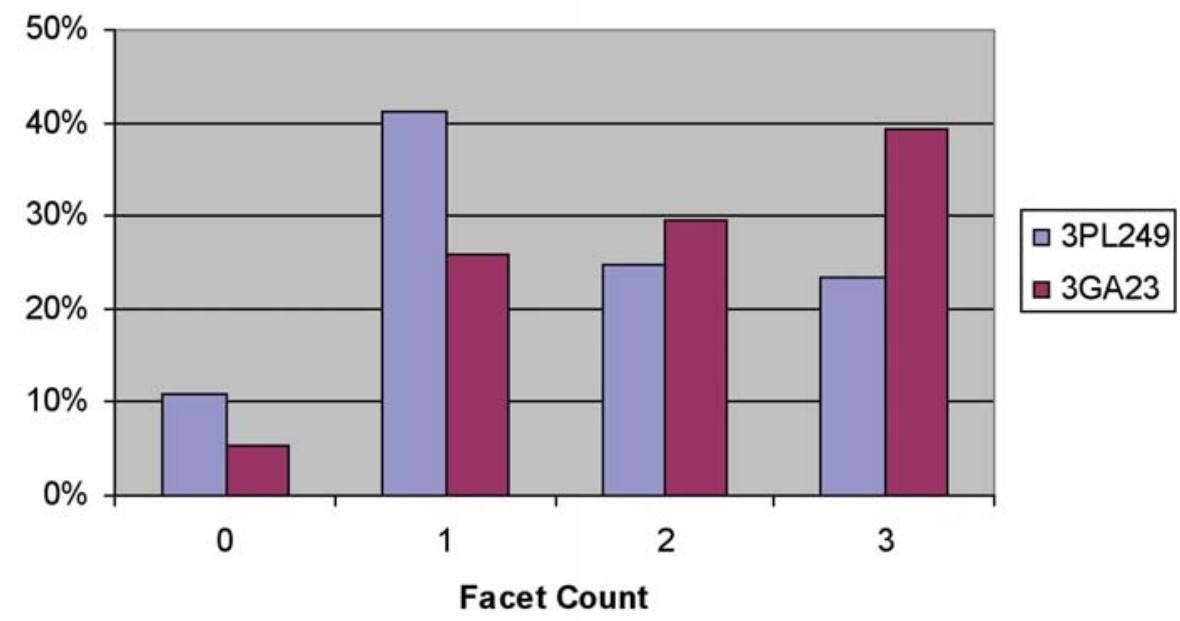

Figure 5. Flake Striking Platform Morphology. 


\begin{tabular}{|c|c|c|c|c|}
\hline \multicolumn{5}{|c|}{ Platform thickness $(\mathrm{mm})$ : } \\
\hline & \multicolumn{2}{|c|}{$3 G A 23$} & \multicolumn{2}{|c|}{$3 P L 349$} \\
\hline $1-3$ & 107 & $62.9 \%$ & 1 & $1.4 \%$ \\
\hline $4-6$ & 48 & $28.2 \%$ & 26 & $35.6 \%$ \\
\hline $7-9$ & 10 & $5.9 \%$ & 17 & $23.3 \%$ \\
\hline $10-12$ & 2 & $1.2 \%$ & 12 & $16.4 \%$ \\
\hline $13-15$ & 3 & $1.8 \%$ & 9 & $12.3 \%$ \\
\hline $16-18$ & 0 & $0.0 \%$ & 5 & $6.8 \%$ \\
\hline \multirow[t]{2}{*}{$19-21$} & 0 & $0.0 \%$ & 3 & $4.1 \%$ \\
\hline & 170 & $100.0 \%$ & 73 & $100.0 \%$ \\
\hline
\end{tabular}

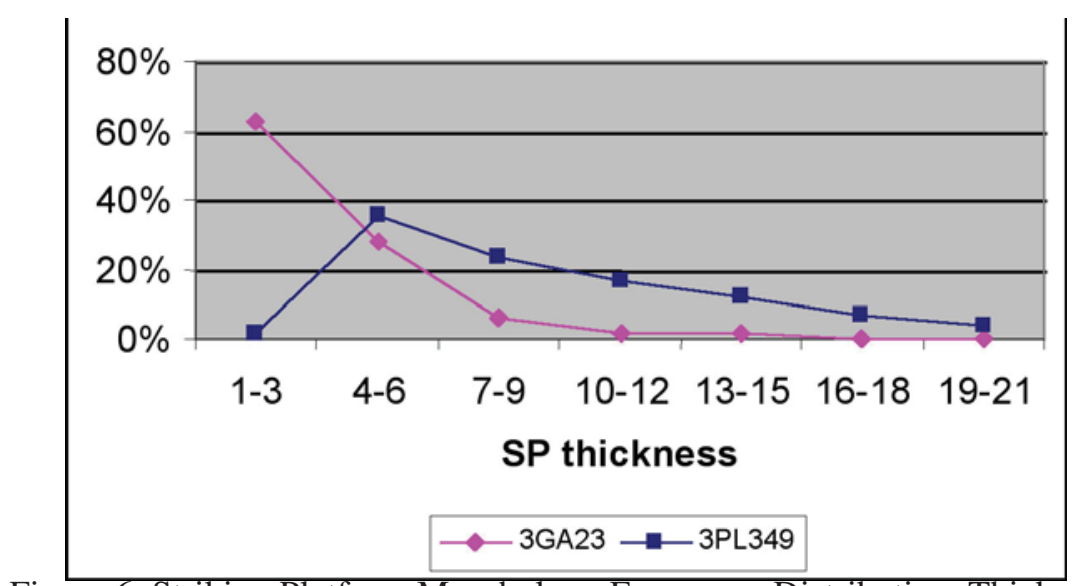

Figure 6. Striking Platform Morphology Frequency Distribution, Thickness.

\section{CONCLUSIONS}

This work is preliminary, but encouraging. Looking just at samples of novaculite debitage from two sites, we have the beginnings of an analysis protocol that can be used to answer questions about how lithic reduction activities took place across space as raw material was obtained from quarries, worked into easily-transportable packages, and taken home (or traded away) to be worked into tools. Using efficient and replicable methods like size-sorting debitage, identifying cortex and shatter, and looking at flake striking platform morphology (see also Bradbury and Carr 2004), we can pull patterns from the thousands of pieces of debitage. These patterns can be compared between sites, giving each site a role in our interpretations of the novaculite tool production and exchange systems. Recognizing differences between quarry and workshop/habitation sites allows us to reconstruct the spatial organization, which is a first step towards understanding the social organization of novaculite tool production.

While the analysis presented here compares two site assemblages, there may well be variation within each site that can be explored further. Using both mass analysis and individual flake analysis, different raw materials or debitage from certain features or deposits within a site could be characterized more specifically (see, for example, analyses by Baumler and Davis 2004; Root 2004). The problem of mixed assemblages has been getting more attention with use of regression analysis, resulting in estimates of the proportion of a debitage 

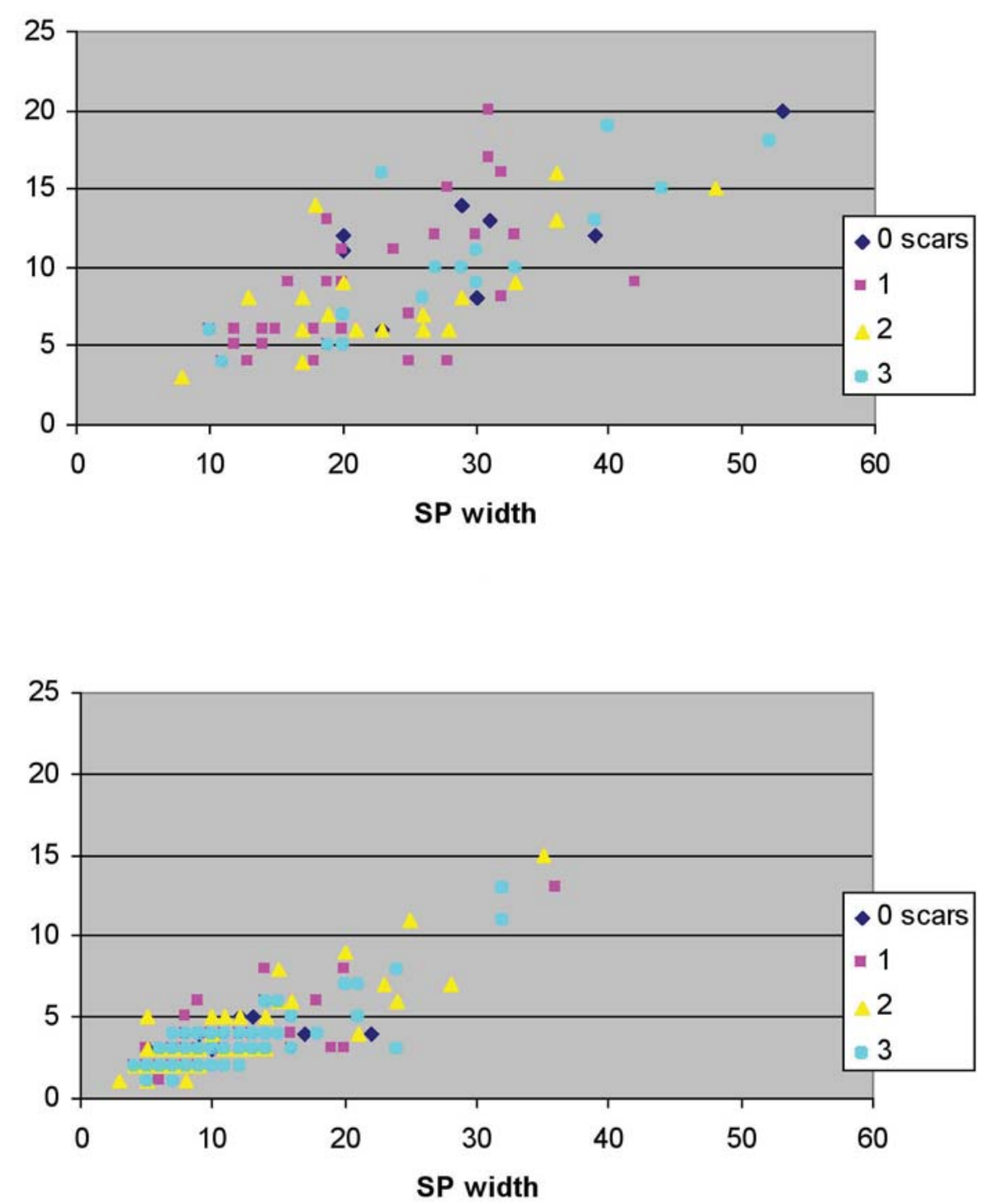

Figure 7. Striking Platform Morphology: top, 3GA23; bottom, 3PL349.

sample that results from core reduction versus biface or tool production (Bradbury and Carr 2004:77-82; Carr and Bradbury 2001:134-141). Certainly examining cores, bifaces, and tools, in addition to the debitage, will help interpret differences between the two sites discussed in this article.

Ideally, we should be comparing contemporaneous sites, and the novaculite used at the workshop or habitation sites should be sourced to specific quarries. We should compare sites that were linked in the past: a habitation site like 3GA23 compared with the quarry site upstream, or a quarry site like 3PL349 compared with a nearby workshop site. Andrews, Murtha, and Scheetz's (2004) recent article on the Hatch jasper quarry and neighboring Houserville habitation site complex in Pennsylvania gives us a model for the potential for this kind of study. There, decortication, heat treatment, and "lithic processing up to the stage immediately preceding formal tool manufacture" took place at the quarry site, while later reduction and tool manufacturing activities were represented by debris at the Houserville site complex (Andrews et al. 2004:83). 
Finally, we also need to keep in mind that lithic debitage results not only from tool production but from tool use, rejuvenation, and recycling as well. Consumption is often discussed in terms of stone tool assemblages (e.g., tool morphology and function, use-wear studies), less often in terms of the lithic debitage byproducts (but see Dockall and Shafer 1993; Koldehoff and Carr 2001; McAnany 1989). Differentiating edge damage from platform preparation during tool production from tool edge use-wear is a concern of microwear analysts (e.g., Huckabay 1981) but may also be raised during debitage analysis (e.g., Johnson 1981:134-135). Roger Coleman (2002:53, 2003:37-38) addresses the issue of identifying debris from novaculite tool maintenance specifically when interpreting the presence of late stage reduction debris on workshop sites. The lithic reduction process included not only tool manufacture but use and reuse as well, and debitage assemblages may reflect this.

\section{ACKNOWLEDGEMENTS}

An earlier version of this work was presented in the "Lithic Reduction Analysis and Problems in Prehistory" Symposium, organized by Harry Lerner, at the Society for American Archaeology, 70th Annual Meeting, Salt Lake City, April 2, 2005. I appreciate the comments of symposium organizer Harry Lerner and symposium discussants Lucy Lewis Johnson and Michael Shott on that paper.

\section{REFERENCES CITED}

Ahler, S. A.

1989a Experimental Knapping with KRF and Midcontinent Cherts: Overview and Applications. In Experiments in Lithic Technology, edited by D. S. Amick and R. P. Mauldin, pp. 199-234. British Archaeological Reports, Vol. 528. BAR International Series, Oxford, England.

1989b Mass Analysis of Flaking Debris: Studying the Forest Rather than the Tree. In Alternative Approaches to Lithic Analysis, edited by D. O. Henry and G. H. Odell, pp. 85-118. Archaeological Papers No. 1. American Anthropological Association, Washington, D.C.

Ahler, S. A. and J. VanNest

1984 Temporal Change in Knife River Flint Reduction Strategies. In Lithic Resource Procurement: Proceedings from the Second Conference on Prehistoric Chert Exploitation, edited by S. C. Vehik, pp. 183-198. Occasional Paper No. 4. Center for Archaeological Investigations, Southern Illinois University, Carbondale.

Andrefsky, W., Jr.

2001 Emerging Directions in Debitage Analysis. In Lithic Debitage: Context, Form, Meaning, edited by W. Andrefsky, Jr., pp. 2-14. University of Utah Press, Salt Lake City.

2004 Partitioning the Aggregate: Mass Analysis and Debitage Assemblages. In Aggregate Analysis in Chipped Stone, edited by C. T. Hall and M. L. Larson, pp. 201-210. University of Utah Press, Salt Lake City.

Andrews, B. W., T. M. Murtha, Jr., and B. Scheetz

2004 Approaching the Hatch Jasper Quarry from a Technological Perspective: A Study of Prehistoric Stone Tool Production in Central Pennsylvania. Midcontinental Journal of Archaeology 29(1):63-101.

Baker, C. M.

1974 A Study of Aboriginal Novaculite Exploitation in the Ouachita Mountains of South-Central Arkansas. Master's Thesis, Department of Anthropology, University of Arkansas, Fayetteville.

Baumler, M. F. and L. B. Davis

2004 The Role of Small-Sized Debitage in Aggregate Lithic Analysis. In Aggregate Analysis in Chipped Stone, edited by C. T. Hall and M. L. Larson, pp. 45-64. University of Utah Press, Salt Lake City. 
Birmingham, N. R.

1984 Lithic Assemblages of the Moline Chert Source Area, Rock Island and Henry Counties, Illinois. In Lithic Resource Procurement: Proceedings from the Second Conference on Prehistoric Chert Exploitation, edited by S. C. Vehik, pp. 133-152. Occasional Paper No. 4. Center for Archaeological Investigations, Southern Illinois University, Carbondale.

Bradbury, A. P.

1998 The Examination of Lithic Artifacts from an Early Archaic Assemblage: Strengthening Inferences through Multiple Lines of Evidence. Midcontinental Journal of Archaeology 23(2):263-288.

Bradbury, A. P. and P. J. Carr

2004 Combining Aggregate and Individual Methods of Flake Debris Analysis: Aggregate Trend Analysis. North American Archaeologist 25(1):65-90.

Carr, P. J. and A. P. Bradbury

2001 Flake Debris Analysis, Levels of Production, and the Organization of Technology. In Lithic Debitage: Context, Form, Meaning, edited by W. Andrefsky, Jr., pp. 126-146. University of Utah Press, Salt Lake City.

Coleman, R. E.

2002 Draft Report for Archaeological Investigation at Brier Creek (3MN2181), Montgomery County, Arkansas. Ouachita Cultural Resources Report No. 207. USDA, Forest Service, Ouachita National Forest, Hot Springs, Arkansas.

2003 Novaculite Acquisition and Use at Little Missouri Falls: An Early Middle Archaic Site in Montgomery County, Arkansas. The Arkansas Archeologist 42:15-43.

Coleman, R., P. S. Gardner, J. Hilliard, M. A. Pfeiffer, and J. Stewart

1999 Excavations in the Shady Lake Recreation Area and Vicinity, 1992-1993, Ouachita National Forest. The Arkansas Archeologist 38:1-54.

Coleman, R. E. and R. L. Guendling

2000 Blaylock Creek Site. In Forest Farmsteads: A Millennium of Human Occupation at Winding Stair in the Ouachita Mountains, edited by A. M. Early, pp. 29-54. Research Series 57. Arkansas Archeological Survey, Fayetteville.

Costin, C. L.

2001 Craft Production Systems. In Archaeology at the Millennium: A Sourcebook, edited by G. M. Feinman and T. D. Price, pp. 273-327. Kluwer Academic/Plenum Publishers, New York.

Crabtree, D. E.

1972 An Introduction to Flintworking. Occasional Papers No. 28. Idaho State University Museum, Pocatello, Idaho.

Dockall, J. E. and H. J. Shafer

1993 Testing the Producer-Consumer Model for Santa Rita Corozal, Belize. Latin American Antiquity 4(2):158-179.

Dowd, A. S

1998 Lithic Procurement and Social Complexity in New York's Hudson River Valley. Ph.D. dissertation, Department of Anthropology, Brown University, Providence, Rhode Island.

Early, A. M. (editor)

2000 Forest Farmsteads: A Millennium of Human Occupation at Winding Stair in the Ouachita Mountains. Research Series 57. Arkansas Archeological Survey, Fayetteville.

Etchieson, M.

1997 Prehistoric Novaculite Quarries in the Ouachita Mountains. Paper presented at the Annual Meeting of the Society for American Archaeology, Nashville, Tennessee. Web published at http://www.fs.fed.us/oonf/history/nova/ novaculite.htm.

Featherstonhaugh, G. W.

1968 [1844] Excursion through the Slave States, from Washington on the Potomac to the Frontier of Mexico; with Sketches of Popular Manners and Geological Notices. Harper \& Brothers. Reprint edition (1968), Negro Universities Press, Greenwood Publishing, New York. 
Funk, R. E.

2004 An Ice Age Quarry-Workshop: The West Athens Hill Site Revisited. Bulletin 504. New York State Museum, New York State Education Department, Albany.

Griswold, L. S.

1892 Whetstones and the Novaculites of Arkansas. Volume III of Annual Report of the Geological Survey of Arkansas for 1890, by John C. Branner. Press Printing Co., Little Rock, Arkansas.

Guendling, R. L.

2000 Bug Spot Site. In Forest Farmsteads: A Millennium of Human Occupation at Winding Stair in the Ouachita Mountains, edited by A. M. Early, pp. 55-68. Research Series 57. Arkansas Archeological Survey, Fayetteville.

Harrington, M. R.

1920 Certain Caddo Sites in Arkansas. Indian Notes and Monographs, Museum of the American Indian, Heye Foundation, New York.

Hatch, J. W.

1994 The Structure and Antiquity of Prehistoric Jasper Quarries in the Reading Prong, Pennsylvania. Journal of Middle Atlantic Archaeology 10:23-47.

Hatch, J. W. and P. E. Miller

1985 Procurement, Tool Production, and Sourcing Research at the Vera Cruz Jasper Quarry in Pennsylvania. Journal of Field Archaeology 12:219-230.

Hemmings, E. T.

1982 Human Adaptations in the Grand Marais Lowland. Research Series No. 17. Arkansas Archeological Survey, Fayetteville.

Hilliard, J. E.

1995 A Preliminary Report on 3PL349, A Novaculite Quarry Site near the Shady Lake Recreation Area, Polk County, Arkansas. In Archeological Investigations in the Southern Ouachita Mountains: Excavations at the Shady Lake Recreation Area and Vicinity, by J. H. Stewart, R. E. Coleman, J. E. Hilliard, M. A. Pfeiffer, M. Etchieson, C. R. Ewen, B. Williams, and P. S. Gardner, pp. 67-72. Project Report 856. Arkansas Archeological Survey, Fayetteville.

Holbrook, D. F. and C. G. Stone

1979 Arkansas Novaculite - A Silica Resource. Arkansas Geological Commission, Little Rock.

Holmes, W. H.

1891 Aboriginal Novaculite Quarries in Garland County, Arkansas. American Anthropologist 4 (old series):313-316.

1974 [1919] Handbook of Aboriginal American Antiquities, Part I, Introductory, The Lithic Industries. Bulletin 60. Smithsonian Institution, Bureau of American Ethnology, Washington, D.C. Reprinted 1974, Burt Franklin, New York, New York.

Huckabay, A. K.

1981 Edge Modification of Chert Artifacts: A Microscopic Analysis. Appendix 2 In Lithic Procurement and Utilization Trajectories: Analysis, Yellow Creek Nuclear Power Plant Site, Tishomingo County, Mississippi, Volume II, by J. K. Johnson. Publications in Anthropology No. 28, Tennessee Valley Authority, and Archaeological Papers of the Center for Archaeological Research, No. 1, University of Mississippi, University, Mississippi.

Ingbar, E. E., K. Ataman, and M. W. Moore

1992 Debitage. In Archaeological Investigations at Tosawihi: A Great Basin Quarry. Part 3: A Perspective from Locality 36, edited by R. G. Elston and C. Raven, pp. 49-82. Report prepared for Bureau of Land Management, Elko, Nevada, and Ivanhoe Gold Company, Winnemucca, Nevada, by Intermountain Research, Silver City, Nevada.

Jeter, M. D. and H. E. Jackson

1994 Poverty Point Extraction and Exchange: The Arkansas Lithic Connection. In "Exchange in the Lower Mississippi Valley and Contiguous Areas at 1100 B.C.”, edited by J. Gibson. Louisiana Archaeology 21:133-206. 
Johnson, J. K.

1981 Lithic Procurement and Utilization Trajectories: Analysis, Yellow Creek Nuclear Power Plant Site, Tishomingo County, Mississippi, Volume II. Publications in Anthropology No. 28, Tennessee Valley Authority, and Archaeological Papers of the Center for Archaeological Research, No. 1, University of Mississippi, University, Mississippi.

1984 Measuring Prehistoric Quarry Site Activity in Northeastern Mississippi. In Prehistoric Chert Exploitation: Studies from the Midcontinent, edited by B. M. Butler and E. E. May, pp. 225-235. Occasional Paper No. 2. Southern Illinois University, Center for Archaeological Investigations, Carbondale.

1989 The Utility of Production Trajectory Modeling as a Framework for Regional Analysis. In Alternative Approaches to Lithic Analysis, edited by D. O. Henry and G. H. Odell, pp. 119-138. Archaeological Papers No. 1. American Anthropological Association, Washington, D.C.

Keller, W. D., C. G. Stone, and A. L. Hoersch

1985 Textures of Paleozoic Chert and Novaculite in the Ouachita Mountains of Arkansas and Oklahoma and Their Geological Significance. Geological Society of America Bulletin 96:1353-1363.

Koldehoff, B. T. and P. J. Carr

2001 Chipped Stone Technology: Patterns of Procurement, Production, and Consumption. In Excavations at Wickliffe Mounds, edited by K. W. Wesler, Chapter 10 on CD-ROM. University of Alabama Press, Tuscaloosa.

Magne, M. P. R.

1985 Lithics and Livelihood: Stone Tool Technologies of Central and Southern Interior British Columbia. National Museum of Man, Mercury Series, Paper No. 133. Archaeological Survey of Canada, National Museums of Canada, Ottawa.

Martin, W. A., with contributions by A. M. Early and B. Watkins

1982 An Intensive Archeological Survey of a Barite Mining District in Montgomery County, Arkansas. In Fancy Hill: Archeological Studies in the Southern Ouachita Mountains, edited by A. M. Early and W. F. Limp, pp. 1-182. Research Series No. 16. Arkansas Archeological Survey, Fayetteville.

McAnany, P. A.

1989 Stone-Tool Production and Exchange in the Eastern Maya Lowlands: The Consumer Perspective from Pulltrouser Swamp, Belize. American Antiquity 54(2):332-346.

Morrow, J. E.

1996 The Organization of Early Paleoindian Lithic Technology in the Confluence Region of the Mississippi, Illinois, and Missouri Rivers. Ph.D. dissertation, Department of Anthropology, Washington University, St. Louis, Missouri.

1997 End Scraper Morphology and Use-Life: An Approach for Studying Paleoindian Lithic Technology and Mobility. Lithic Technology 22(1):76-91.

Morrow, T.

1997 A Chip off the Old Block: Alternative Approaches to Debitage Analysis. Lithic Technology 22(1):51-69.

Odell, G. H.

2004 Lithic Analysis. Kluwer Academic/Plenum Publishers, New York.

Parry, W. J. and R. L. Kelly

1987 Expedient Core Technology and Sedentism. In The Organization of Core Technology, edited by J. K. Johnson and C. A. Morrow, pp. 285-304. Westview Press, Boulder, Colorado.

Patterson, L. W.

1990 Characteristics of Bifacial-Reduction Flake-Size Distribution. American Antiquity 55(3):550-558.

Perttula, T. K.

1984 Patterns of Prehistoric Lithic Raw Material Utilization in the Caddoan Area: The Western Gulf Coastal Plain. In Prehistoric Chert Exploitation: Studies from the Midcontinent, edited by B. M. Butler and E. E. May, pp. 129148. Occasional Paper No. 2. Center for Archaeological Investigations, Southern Illinois University, Carbondale. 
Root, M. J.

2004 Technological Analysis of Flake Debris and the Limitations of Size-Grade Techniques. In Aggregate Analysis in Chipped Stone, edited by C. T. Hall and M. L. Larson, pp. 65-94. University of Utah Press, Salt Lake City.

Schambach, F. F.

1998 Pre-Caddoan Cultures in the Trans-Mississippi South. Research Series No. 53. Arkansas Archeological Survey, Fayetteville.

Shott, M. J.

1994 Size and Form in the Analysis of Flake Debris: Review and Recent Approaches. Journal of Archaeological Method and Theory 1(1):69-110.

1996 Stage Versus Continuum in the Debris Assemblage from Production of a Fluted Biface. Lithic Technology 21:6-22.

Stahle, D. W. and J. E. Dunn

1982 An Analysis and Application of the Size Distribution of Waste Flakes from the Manufacture of Bifacial Stone Tools. World Archaeology 14(1):84-97.

1984 An Experimental Analysis of the Size Distribution of Waste Flakes from Biface Reduction. Technical Paper No. 2. Arkansas Archeological Survey, Fayetteville.

Steuart, C. T., D. F. Holbrook, and C. G. Stone

1984 Arkansas Novaculite: Indians, Whetstones, Plastics, and Beyond. Proceedings of the 19th Forum on the Geology of Industrial Minerals, Ontario Geological Survey Miscellaneous Paper 114 :156-167.

Stewart, J. H.

1995 Excavations at Shady Lake Recreation Area. In Archeological Investigations in the Southern Ouachita Mountains: Excavations at the Shady Lake Recreation Area and Vicinity, by J. H. Stewart, R. E. Coleman, J. E. Hilliard, M. A. Pfeiffer, M. Etchieson, C. R. Ewen, B. Williams, and P. S. Gardner, pp. 41-65. Project Report 856. Arkansas Archeological Survey, Fayetteville.

Stoltman, J. B., J. A. Behm, and H. A. Palmer

1984 The Bass Site: A Hardin Quarry/Workshop in Southwestern Wisconsin. In Prehistoric Chert Exploitation: Studies from the Midcontinent, edited by B. M. Butler and E. E. May, pp. 197-224. Occasional Paper No. 2. Center for Archaeological Investigations, Southern Illinois University, Carbondale.

Thomas, P. M., L. J. Campbell, C. S. Weed, and M. T. Swanson

1982 Fancy Hill: Part II: Archeological Testing at Seven Sites in the Fancy Hill Area, Montgomery County, Arkansas. In Fancy Hill: Archeological Studies in the Southern Ouachita Mountains, edited by A. M. Early and W. F. Limp, pp. 183-306. Research Series No. 16. Arkansas Archeological Survey, Fayetteville.

Trubitt, M. B.

2005 Mapping a Novaculite Quarry in Hot Springs National Park. Caddoan Archeology Journal 14:17-33.

Trubitt, M. B., T. Green, and A. Early

2004 A Research Design for Investigating Novaculite Quarry Sites in the Ouachita Mountains. The Arkansas Archeologist 43:17-62.

Waddell, D. B.

1995 Prehistoric Activity Patterning in the Ouachita Mountain Uplands. In An Archeological Survey of 8,939 acres in the Caddo, Cold Springs, Fourche, Jessieville, Winona, and Womble Districts of the Ouachita National Forest, Garland, Hot Spring, Montgomery, Perry, Scott and Yell Counties in Arkansas, by D. B. Waddell, E. Z. Waddell, K. Hoffman, M. Hughes, and A. Moerbe, pp. 53-120. Project Report No. 66. SPEARS, Inc., West Fork, Arkansas.

Waddell, D. B. and E. Z. Waddell

1992 An Archeological Survey of 7,985 acres in the Winona, Womble, Caddo, Mena, Kiamichi, and Choctaw Districts of the Ouachita National Forest, Arkansas and Oklahoma. Project Report No. 41. SPEARS, Inc., West Fork, Arkansas.

Waddell, D. B., E. Z. Waddell, K. Hoffman, M. Hughes, and A. Moerbe 
1995 An Archeological Survey of 8,939 acres in the Caddo, Cold Springs, Fourche, Jessieville, Winona, and Womble Districts of the Ouachita National Forest, Garland, Hot Spring, Montgomery, Perry, Scott and Yell Counties in Arkansas. Project Report No. 66. SPEARS, Inc., West Fork, Arkansas.

Whittington, D. B.

1969 Arkansas' Oldest Industry. Arkansas Historical Quarterly 28(3):223-230. 



\section{Order Form}

\section{Back Issues of Caddoan Archeology Newsletter and Caddoan Archeology Journal}

\begin{tabular}{|c|c|c|c|c|}
\hline Volume & Price & Quantity & Volume & Price \\
\hline Vol. I, No. 1 & $\$ 2.00$ & & Vol. 7, No. 2 & $\$ 3.00$ \\
\hline Vol. I, No. 2 & $\$ 2.00$ & & Vol. 7, No. 3 & $\$ 3.00$ \\
\hline Vol. I, No. 3 & $\$ 2.00$ & & Vol. 7, No. 4 & $\$ 3.00$ \\
\hline Vol. I, No. 4 & $\$ 2.00$ & & Vol. 8, No. 1 & $\$ 3.00$ \\
\hline Vol. II, No. 1 & $\$ 2.00$ & & Vol. 8, No. 2 & $\$ 3.00$ \\
\hline Vol. II, No. 2 & $\$ 2.00$ & & Vol. 8, No. 3 & $\$ 3.00$ \\
\hline Vol. II, No. 3 & $\$ 2.00$ & & Vol. 8, No. 4 & $\$ 3.00$ \\
\hline Vol. II, No. 4 & $\$ 2.00$ & & Vol. 9, No. 1 & $\$ 3.00$ \\
\hline Vol. III, No. 1 & $\$ 2.00$ & & Vol. 9, No. 2 & $\$ 3.00$ \\
\hline Vol. III, No. 2 & $\$ 2.00$ & & Vol. 9, No. 3/4 & $\$ 6.00$ \\
\hline Vol. III, No. 3 & $\$ 2.00$ & & Vol. 10, No. 1 & $\$ 3.00$ \\
\hline Vol. III, No. 4 & $\$ 2.00$ & & Vol. 10, No. 2 & $\$ 3.00$ \\
\hline Vol. IV, No. 1 & $\$ 3.00$ & & Vol. 10, No. 3 & $\$ 3.00$ \\
\hline Vol. IV, No. 2 & $\$ 3.00$ & & Vol. 10, No. 4 & $\$ 3.00$ \\
\hline Vol. IV, No. 3 & $\$ 3.00$ & & Vol. 11, No. 1/2 & $\$ 6.00$ \\
\hline Vol. IV, No. 4 & $\$ 3.00$ & & Vol. 11, No. 3 & $\$ 3.00$ \\
\hline Vol. 5, No. 1 & $\$ 3.00$ & & Vol. 11, No. 4 & $\$ 3.00$ \\
\hline Vol. 5, No. 2 & $\$ 3.00$ & & Vol. 12, No. 1 & $\$ 3.00$ \\
\hline Vol. 5, No. 3 & $\$ 3.00$ & & Vol. 12, No. 2/3 & $\$ 6.00$ \\
\hline Vol. 5, No. 4 & $\$ 3.00$ & & Vol. 12 , No. 4 & $\$ 3.00$ \\
\hline Vol. 6, No. 1 & $\$ 3.00$ & & Vol. 13, No. 1 & $\$ 3.00$ \\
\hline Vol. 6, No. 2 & $\$ 3.00$ & & Vol. 13, No. 2 & $\$ 3.00$ \\
\hline Vol. 6, No. 3 & $\$ 3.00$ & & Vol. 14 & $\$ 5.00$ \\
\hline Vol. 6, No. 4 & $\$ 3.00$ & & Vol. 15 & $\$ 15.00$ \\
\hline
\end{tabular}

Vol. 7, No. $1 \quad \$ 3.00$

Send order information and checks (made out to Caddoan Archeology) to: Caddoan Archeology, P.O. Box 8419, Austin, TX 78712-8419 
